\title{
KONCEPT TRAJNOSTNO KOMPAKTNEGA MESTA
}

Anja Šulin Košar, univ. dipl. geogr.

Pavšičeva 6, SI-1000 Ljubljana

e-mail: anjasulin@gmail.com

Izvirni znanstveni članek

COBISS 1.01

DOI: 10.4312/dela.41.8.145-164

\section{Izvleček}

Koncept kompaktnega mesta se je pojavil konec 20. st. kot ena od rešitev za trajnostni razvoj mest. Koncept razvoja poudarja mestno gostoto, hkrati pa preprečuje širjenje mest navzven. Pomembna je mešana raba zemljišč, večja gostota poselitve (intenziviranje mesta) ter čim boljša dostopnost za vse prebivalstvo, pri čemer je najpomembnejši razvoj javnega prometnega sistema. Koncept prinaša prednosti, a tudi slabosti, saj prevelika gostota vpliva na kakovost življenja v mestu.

Ključne besede: urbana geografija, kompaktno mesto, trajnostni razvoj, Ljubljana

\section{SUSTAINABLE COMPACT CITY CONCEPT}

\begin{abstract}
The compact city concept has emerged at the end of the 20th century as one of the solutions for sustainable urban development. The concept brings development, which emphasizes urban density, while avoiding urban sprawl. The key features of the concept are mixed land use, construction of higher density (city intensification) as well as better access for the entire population and most importantly, development of the public transport system. The concept has advantages, but also disadvantages, because too much density affects the quality of life in the city.
\end{abstract}

Key words: urban geography, compact city, sustainable development, Ljubljana 


\section{UVOD}

Leta 1987 je Brundtlandova komisija vpeljala koncept trajnostnega razvoja, ki je postal pomemben dejavnik na vseh ravneh prostorskega razvoja. Trajnostni razvoj se je tako vključil tudi v načrtovanje razvoja mest, saj se prav v mestih pojavljajo številni negativni dejavniki, kot so nenadzorovana rast prebivalstva, nenadzorovano širjenje urbanih območij, izguba kmetijskih zemljišč, poraba neobnovljivih naravnih virov ter okoljske emisije, ti pa pomembno vplivajo na prihodnji razvoj mest in kvaliteto bivanja v njih. Če torej želimo mesta ohraniti za prihodnje generacije ter omogočiti kvalitetno življenje vseh njihovih prebivalcev, je potrebno ukrepati. Ena od rešitev za trajnostni razvoj urbanih območij je koncept kompaktnega mesta, ki se je uveljavil v številnih evropskih državah.

Razprave o urbani formi v 80. letih 20. st. so prvič vključevale tudi termin trajnostni razvoj. Ob tem je planiranje postavilo dva glavna cilja, ki jih mesta morajo doseči:

- zmanjšanje potrebe po prevozu (krajši prevozi in uporaba javnega prometa, s tem se zmanjša globalno segrevanje ozračja);

- okoljske koristi, npr. zmanjšanje izgube odprtih prostorov in dragocenih habitatov.

$\mathrm{Z}$ večjo gostoto poselitve $\mathrm{v}$ mestih bi se po nekaterih prepričanjih izboljšala tudi kvaliteta življenja v mestih (Breheny, 1998).

Koncept kompaktnega mesta so prvič predlagali konec 20. st. kot eno od glavnih alternativ za rešitev problema širjenja mest. Koncept se zelo razlikuje od običajnega razvoja mest, saj poudarja večjo gostoto poselitve urbanega prostora, postavlja omejitve za rast mest, spodbuja večnamenski razvoj ter daje večji poudarek vlogi javnega prometa in kakovostnega urbanističnega načrtovanja (Arbury, 2005).

Pomen koncepta kompaktnega mesta v razvojnih dokumentih poudarjajo tudi Evropska unija, OECD ter nekatere države, ki v njem vidijo eno od rešitev za urbani prostorski razvoj. V članku bomo predstavili značilnosti trajnostnega in kompaktnega mesta, njegove prednosti in slabosti ter merila, s katerimi je mogoče spremljati razvoj kompaktnih mest in na podlagi teh pravočasno ukrepati, da kompaktno ne postane tudi manj kakovostno. Hkrati bomo na primeru Ljubljane ugotavljali, ali je koncept kompaktnega mesta prisoten tudi v slovenskem prostoru.

\section{TRAJNOSTNO MESTO}

»Trajnostni sonaravni mestni razvoj vključuje ekonomsko, družbeno in okoljsko trajnost, torej označuje željo po splošnem urbanem blagostanju, visoki kakovosti življenja za vse mestne prebivalce, primernem materialnem blagostanju in stopnji socialne varnosti ter pravičnosti, ob hkratnemu ohranjanju primernih prostorskih, življenjskih pogojev prihodnjim mestnim generacijam. Glede na dolgoročne cilje in odvisnost človeka od okolja, naravnih virov, pa je ključno, da je za doseganje večplastne globalne trajnosti najpomembnejša civilizacijska naloga doseganje okoljske urbane trajnosti, torej aplikacija sistemske ekologije na raven mest. V nekoliko ožjem urbanem pomenu je trajnostni (trajnostni sonaravni) razvoj zasnovan na preprečevanju uničevanja urbanega okolja, 
ohranjanju ambientalnih vrednot za prihodnje rodove in zagotavljanju višanja življenjske ravni za vse prebivalce različnih socialnih skupin na vsem območju mesta.« (Dimitrovska Andrews, Mihelič, Stanič, 2001, str. 6).

$\mathrm{V}$ trajnostnem mestu se spodbuja mešana raba urbanega prostora, okolju prijazna organizacija prometa, varstvo kulturne dediščine in narave, izboljšanje kakovosti bivalnega okolja in sonaravna raba naravnih virov. Mešana raba tako zmanjšuje število in razdalje nujnih voženj, ohranjanje zelenih površin v mestnem središču pa omogoča povezovanje s prehodnim zelenim sistemom mestne regije ter izenačevanje pogojev bivanja v mestu in na podeželju (Koželj, 2007).

Trajnostno mesto bi moralo biti takšne oblike in velikosti, da je primerno za hojo, kolesarjenje in učinkovit javni promet, hkrati pa kompaktno do te mere, da spodbuja socialno interaktivnost (Elkin, McLaren, Hillman, 1991). Nekateri drugi avtorji so predlagali oblike, ki segajo od velikih koncentracij prek idej o hkratni decentralizaciji in kompaktnosti do kompaktnih naselij, ki jih povezuje sistem javnega prometa, ter strategij disperznosti v samozadostnih skupnostih (Haughton,1994). V obstoječih mestih nastane koncept kompaktnosti s procesi, ki okrepijo razvoj in prinašajo priselitve $\mathrm{v}$ mesto, novo naseljeno prebivalstvo pa mesto ponovno oživi. Ideje, ki se skrivajo za pojmom kompaktno mesto, so pomemben sklop v poskusu, da bi našli trajnostne urbane oblike mest (Jenks, Burton, Williams, 1998).

»Sonaravni ideal 21. st. niso večmilijonska mesta, katerih ekološki odtisi v gospodarsko razvitih državah za več kot 100-krat presegajo mestno ozemlje, njihova vsakodnevna oskrba z energijo in materiali pa je vezana praktično na celoten planet. Gosto, sklenjeno, obvladljivo mesto, ki varčuje s prostorom in rešuje komunikacijsko-prometne probleme, postaja urbanistični, trajnostni ideal šibke sonaravnosti, saj med drugim bistveno zmanjšuje ekološke odtise na prebivalca.« (Plut, 2007, str. 15-16).

Da bi dosegli trajnostni razvoj mesta in urbanega prostora, so v večini dokumentov s področja trajnostnega razvoja določili sledeče cilje:

- mešana raba;

- preprečevanje razpršene poselitve oziroma širjenja mest (angl. urban sprawl);

- strnjena poselitvena struktura;

- uravnotežen in policentrični urbani sistem;

- obnova degradiranih urbanih območij;

- revitalizacija obstoječih mestnih območij;

- izboljšanje kakovosti zraka in vode;

- zmanjševanje hrupa;

- kakovostna oskrba s pitno vodo;

- zmanjševanje emisij toplogrednih plinov;

- uporaba obnovljivih virov energije;

- zmanjševanje količine odpadkov;

- razvoj kakovostnega javnega prometa;

- kakovost življenja;

- ohranjanje kulturne dediščine;

- biotska pestrost;

- ohranjanje in širitev javnih zelenih površin. 


\section{KAJ JE KOMPAKTNO MESTO?}

Definiranje kompaktnega mesta je težka naloga, saj enoten model kompaktnega mesta ne obstaja. Lahko pa izpostavimo tri glavne značilnosti:

a) vzorec razvoja, ki poudarja gostoto poselitve in bližino različnih storitev:

- urbana zemljišča so intenzivno izkoriščena;

- strnjeni mestni predeli, ki si sledijo en za drugim oziroma stojijo blizu skupaj;

- jasna meja med mestno in podeželsko rabo zemljišč;

- varni javni prostori;

b) urbana območja, povezana z javnim prometnim omrežjem:

- učinkovita raba urbanih zemljišč;

- sistemi javnega potniškega prometa omogočajo mobilnost v urbanih območjih;

c) dostopnost do lokalnih storitev in delovnih mest:

- mešana raba;

- večina prebivalcev ima dostop do lokalnih storitev peš ali z uporabo javnega potniškega prometa (Compact city ..., 2012).

Prva sta termin kompaktno mesto uporabila Dantzig in Saaty (1973), ki sta med glavnimi značilnostmi takega mesta navedla:

- urbana oblika: visoka gostota poselitve, manjša odvisnost od avtomobila (kot posledica visoke gostote), jasna meja med mestom in okolico;

- prostorske značilnosti: mešana raba zemljišč, raznolikost, jasna identiteta;

- družbene funkcije: socialna pravičnost, samozadostnost pri vsakdanjem življenju, neodvisna mestna uprava (Dantzig, Saaty, 1973).

S konceptom kompaktnega mesta so se ukvarjali tudi drugi avtorji. Breheny (1998) npr. predstavi kompaktno mesto kot mesto visoke gostote poselitve, mesto mešane rabe, kjer se rast spodbuja znotraj meja obstoječih urbanih območij, brez kakršnegakoli razvoja izven le-teh. Zanj je koncept kompaktnega mesta kot rešitev okoljskih in prostorskih težav najbolj jasno opisan v Green paper on the urban environment (1990), ki pravi, da prizadevanja za razvoj kompaktnih mest ne temeljijo strogo le na okoljskih merilih porabe energije in stopnjah emisij, temveč tudi na kakovosti življenja. Cilj je, da se prepreči izogibanje problemom mesta $\mathrm{z}$ razširitvijo na obrobje, hkrati pa mesto reši svoje probleme v okviru obstoječih meja (Thomas, Cousins, 1998).

Tudi Neuman (2005) je razmišljal podobno kot drugi avtorji in med značilnostmi kompaktnega mesta izpostavil naslednje:

- visoka gostota poselitve in delovnih mest;

- mešana raba zemljišč;

- bližina različnih rab in relativno majhne velikosti parcel;

- močna družbena in ekonomska interakcija;

- sosedski razvoj;

- urbani razvoj z jasno določenimi mejami;

- urejena urbana infrastruktura (kanalizacija, vodovod); 
- multi-modalni transport;

- visoka stopnja dostopnosti: lokalno, regionalno;

- visoka stopnja povezovalnosti ulic, vključujoč pločnike in kolesarske steze;

- visoka stopnja neprepustne površinske pokritosti;

- nizek delež odprtega prostora;

- enoten nadzor nad načrtovanjem prostorskega razvoja;

- zmožnost financiranja mestnih objektov in infrastrukture (z vidika zadostnega proračuna in ustrezne zakonodaje) (Neuman, 2005).

Obstajajo različne teorije o tem, kakšne oblike naj bi bilo kompaktno mesto. Med nekaterimi avtorji prevladuje prepričanje, da kompaktno mesto spominja na srednjeveško mesto s koncentracijo aktivnosti v zelo gostem mestu, ki se jasno loči od podeželja, po navadi v obliki mestnega obzidja. Haughton (1994) pa je predstavil nekaj drugih rešitev, na podlagi katerih lahko sklepamo, da kompaktno mesto ni nujno tako kompaktno in s tako ostrimi mejami kot srednjeveško mesto; avtorja med kompaktna mesta tako uvrščata:

- velika koncentrirana središča;

- decentralizirana, vendar koncentrirana in kompaktna naselja, povezana z javnim prometom;

- razpršene samozadostne skupnosti (Frey, 1999).

\section{PREDNOSTI IN SLABOSTI KONCEPTA KOMPAKTNIH MEST}

Pri raziskovanju koncepta kompaktnega mesta so različni avtorji (Frey, Breheny, Haughton in drugi) izpostavljali tako prednosti kot slabosti tega koncepta. Frey (1999) je npr. izpostavil naslednje prednosti:

- visoka stopnja zadrževanja urbanega razvoja; ponovna uporaba infrastrukture in že komunalno opremljenih zemljišč; pomlajevanje obstoječih urbanih območij in posledično mestne vitalnosti; kot posledica zadrževanja in visoke gostote prebivalstva se oblikuje kompaktno mesto in hkrati ohranja podeželje;

- cenovno dostopen javni promet, ki pokriva dnevne potrebe tistih, ki nimajo osebnega avtomobila, torej večine mestnega prebivalstva, zaradi česar se povečata dostopnost in mobilnost;

- javni promet pomeni zmanjšanje prometnih površin, zmanjšanje onesnaževanja in tveganja za smrt ali poškodbe v prometu; zmanjševanje prometnih izdatkov vodi $\mathrm{k}$ manjšemu onesnaževanju, zastoji so porazdeljeni na več prometnic in so manjši;

- ohranjanje mešane rabe mestnega prostora kot posledica visoke gostote prebivalstva; zmanjšanje prevoženih razdalj zaradi mešane rabe in višje gostote prebivalstva; kolesarjenje in hoja kot najbolj energetsko učinkovit način dostopa do storitev znotraj mesta; manjša odvisnost od osebnega avtomobila;

- boljše okolje - zaradi zmanjšanih emisij toplogrednih plinov ter manjše porabe fosilnih goriv - in posledično boljše zdravje;

- nižji stroški ogrevanja kot posledica gostejše urbane strukture, z manjšo porabo energije in manjšim onesnaževanjem; 
- možnosti mešanja različnih družbenih skupin, še posebej, če ga omogoča široka paleta tipov stanovanj in posesti v soseskah;

- koncentracija dejavnosti v lokalnih skupnostih in soseskah; rezultat tega je visoka kakovost življenja, večja varnost in bolj živahno okolje, kot tudi podpora za poslovneže in storitve (izboljšani poslovni in trgovinski objekti) (Frey, 1999).

A v konceptu je Frey (1999) prepoznal tudi kar nekaj slabosti:

- koncept kompaktnega mesta je $\mathrm{v}$ nasprotju $\mathrm{z}$ vse večjo priljubljenostjo suburbanih in semiruralnih območij; še posebej ob visokih gostotah se lahko prednosti koncentracije prevesijo v slabosti zaradi prometnih zastojev, ki bi prevladali nad koristmi manjše porabe energije v kompaktnem mestu; hkrati telekomunikacije omogočajo ljudem, da živijo na podeželju, kar je v nasprotju s konceptom kompaktnega mesta;

- pojem zeleno mesto (ki ga prav tako spodbuja Evropska komisija) je v nasprotju s konceptom kompaktnega mesta; če mestu vzamemo odprte površine, trpi kvaliteta okolja;

- politika kompaktnega mesta bi povzročila zanemarjanje podeželskih skupnosti in prej nastalih centrov rasti, ki so nastali v času politike razpršenosti; tak gospodarski razvoj podeželja bi bil ogrožen zaradi aktivnosti v okviru obstoječih mest;

- kompaktno mesto bi povzročilo zastoje, povečalo onesnaževanje, povzročilo izgubo privlačnosti prostora in zmanjšanje zasebnosti, kot lahko to vidimo v mestih kot so Kalkuta, Kairo in Rio de Janeiro;

- v kompaktnem mestu bi se povečala rasna segregacija zaradi visokih stroškov nastanitve $\mathrm{v}$ centru mesta in $\mathrm{v}$ bolj privilegiranih zunanjih predmestjih;

- obseg varčevanja energije s pomočjo koncentracije je zanemarljiv v primerjavi s slabostmi, ki jih povzroča;

- optimalna pasivna raba sončne energije zahteva nižje gostote zazidave, saj največje prihranke energije dosežemo s samostojnimi hišami in dvojčki, prihranki pa so manjši pri terasasti in večstanovanjski gradnji;

- s spodbujanjem visoke gostote poselitve kompaktno mesto ne upošteva negotovosti pri rasti prebivalstva in razpršenosti, kar pomeni, da se kompaktno mesto ne bi moglo odzvati na napovedano povečanje števila gospodinjstev;

- moč vpliva na lokalne odločitve in možnost dostopa do različnih lokalnih storitev se zmanjšata s povečanjem obsega kompaktnega mesta;

- kompaktno mesto pomeni velike finančne spodbude, ki so ekonomsko sumljive, ter visoko stopnjo družbenega nadzora, ki je politično nesprejemljiv (Frey, 1999).

Koncept kompaktnega mesta lahko izboljša videz in vitalnost mesta, z modernejšo arhitekturo prenovi območja in izboljša vitalnost, s ponovno uporabo in nadgradnjo območij pa lahko vpliva tudi na videz mesta. S povečanim priseljevanjem lahko mesto postane bolj živahno in spodbudi več kulturnih dejavnosti in objektov. Tako bi bila podoba mesta ponovno oživljena, postala pa bi tudi bolj privlačna tako za prebivalstvo kot obiskovalce (Williams, Burton, Jenks, 1998).

Dilema v konceptu kompaktnega mesta je predvsem $\mathrm{v}$ dejstvu, da hkrati teži $\mathrm{k}$ rabi obstoječih zemljišč in ohranitvi zelenih površin - uporaba obstoječih zemljišč lahko 
mnogokrat vodi k uničenju bogatih naravnih mestnih habitatov. Hkrati pa je vprašljiva tudi kvaliteta življenja, saj ljudje v želji po povečanem obsegu prostega časa, zavrnitvi dela kot identitete posameznika in večji kontroli nad življenjskimi odločitvami težijo k večji kakovosti življenja, ta pa se v njihovih očeh pojavlja kot življenje na podeželju v lastni enodružinski hiši. Ob tem mnogi okoljevarstveniki menijo, da so ljudje pripravljeni prenašati vedno večje zastoje, onesnaževanje in vsesplošno poslabšanje okolja, dokler bodo uživali svobodo in ugodje moderne potrošniške družbe (Thomas, Cousins, 1998).

Za razliko od Freya, v OECD-ju prepoznavajo v konceptu kompaktnega mesta predvsem prednosti, oziroma je po njihovem mnenju negativne posledice mogoče preprečiti, še preden se pojavijo (Compact city ..., 2012). V OECD-ju prepoznavajo v kompaktnem mestu šest značilnosti, ki pripomorejo k doseganju urbane trajnosti. V diskusiji je OECD šel še nekoliko dlje in definiral koristi, ki jih na podlagi omenjenih značilnosti kompaktno mesto prispeva $\mathrm{k}$ urbani trajnosti (preglednica 1).

\section{Preglednica 1: Značilnosti kompaktnega mesta}

Table 1: Compact city characteristics

\begin{tabular}{|c|c|c|c|}
\hline Značilnosti & Okoljske koristi & Družbene koristi & \begin{tabular}{|l|} 
Ekonomske koristi \\
\end{tabular} \\
\hline $\begin{array}{l}\text { Krajše prevožene } \\
\text { razdalje znotraj mesta }\end{array}$ & $\begin{array}{l}\text { Manjša onesnaženost } \\
\text { zaradi avtomobilov, } \\
\text { manjše emisije } \mathrm{CO}_{2}\end{array}$ & $\begin{array}{l}\text { Večja dostopnost zaradi } \\
\text { manjših stroškov }\end{array}$ & $\begin{array}{l}\text { Višja produktivnost } \\
\text { zaradi krajšega potoval- } \\
\text { nega časa delavcev }\end{array}$ \\
\hline $\begin{array}{l}\text { Manjša odvisnost od } \\
\text { avtomobila }\end{array}$ & $\begin{array}{l}\text { Manjša onesnaženost } \\
\text { zaradi avtomobilov, } \\
\text { manjše emisije } \mathrm{CO}_{2}\end{array}$ & $\begin{array}{l}\text { Nižji prevozni stroški, } \\
\text { večja mobilnost ljudi } \\
\text { brez avtomobila, izbolj- } \\
\text { šano zdravje ljudi zaradi } \\
\text { več kolesarjenja in hoje }\end{array}$ & $\begin{array}{l}\text { Razvoj zelenih delovnih } \\
\text { mest/tehnologij }\end{array}$ \\
\hline $\begin{array}{l}\text { Širša izraba energije } \\
\text { in njena lokalna } \\
\text { proizvodnja }\end{array}$ & $\begin{array}{l}\text { Manjša poraba energije } \\
\text { na prebivalca, manjše } \\
\text { emisije } \mathrm{CO}_{2}\end{array}$ & - & $\begin{array}{l}\text { Razvoj zelenih delovnih } \\
\text { mest/tehnologij, večja } \\
\text { energetska neodvisnost }\end{array}$ \\
\hline $\begin{array}{l}\text { Optimalna raba naravnih } \\
\text { virov in več priložnosti } \\
\text { za povezovanje na } \\
\text { relaciji mesto-podeželje }\end{array}$ & $\begin{array}{l}\text { Manjše emisije } \mathrm{CO}_{2} \\
\text { zaradi krajšega tran- } \\
\text { sporta hrane, ohranitev } \\
\text { kmetijskih zemljišč in } \\
\text { naravne biodiverzitete na } \\
\text { podeželju }\end{array}$ & $\begin{array}{l}\text { Večja kvaliteta življenja } \\
\text { zaradi povečanih } \\
\text { rekreacijskih aktivnosti }\end{array}$ & $\begin{array}{l}\text { Gospodarski razvoj } \\
\text { podeželja (urbano } \\
\text { kmetovanje, obnovljiva } \\
\text { energija, itd.) }\end{array}$ \\
\hline $\begin{array}{l}\text { Učinkovitejše izvajanje } \\
\text { javnih služb }\end{array}$ & - & $\begin{array}{l}\text { Z izboljšano učinkovi- } \\
\text { tostjo javnih služb se } \\
\text { poveča socialna varnost }\end{array}$ & $\begin{array}{l}\text { Nižje investicije v } \\
\text { infrastrukturo in stroški } \\
\text { njenega vzdrževanja }\end{array}$ \\
\hline $\begin{array}{l}\text { Boljša dostopnost do } \\
\text { raznolikih lokalnih } \\
\text { storitev in služb }\end{array}$ & - & $\begin{array}{l}\text { Večja kvaliteta življenja } \\
\text { zaradi dostopa do lokal- } \\
\text { nih storitev (trgovine, } \\
\text { bolnišnice itd.) }\end{array}$ & $\begin{array}{l}\text { Visoka kvaliteta živ- } \\
\text { ljenja privablja visoko } \\
\text { kvalificirano delovno } \\
\text { silo, višja produktivnost } \\
\text { zaradi večje raznolikosti, } \\
\text { vitalnosti, inovativnosti } \\
\text { in kreativnosti }\end{array}$ \\
\hline
\end{tabular}

Vir/Source: Compact city ..., 2012 


\section{PREVERJANJE KOMPAKTNOSTI}

Zaradi pomislekov, ki jih vzbuja koncept kompaktnega mesta, je potrebno v načrtovanje urbanega prostora vključiti primerljive kazalnike, ki bi spremljali uspešnost politike uresničevanja kompaktnih mest. S spremljanjem t. i. kompaktnosti bi nadzorovali morebitne negativne posledice take politike in jih še pred samo izvedbo preprečili.

Da bi bila politika kompaktnega mesta uspešna, je potrebno učinkovitost uresničevanja takega mesta nadzorovati. OECD je v ta namen določil kazalnike, s pomočjo katerih je mogoče izmeriti kompaktnost in vpliv kompaktnosti na urbano trajnost ter ugotoviti, ali prinaša takšno mesto negativne učinke. Obstajajo sicer različni nabori kazalnikov, ki spremljajo stanje in razvoj mest (Cities data book. Urban indicators for managing cities, 2001; City statistics - Urban Audit, 2014; Global city indicators facility, 2014; Hammer in sod., 2011; Urban indicators, 2014), in tudi nabor, ki ga je predlagal OECD in znotraj katerega je definiranih 18 ključnih kazalnikov za analiziranje uresničevanja politike kompaktnega mesta (Compact city ..., 2012) (preglednica 2).

Preglednica 2: Kazalniki za analiziranje politike uresničevanja kompaktnega mesta Table 2: Compact city policy analysis indicators

\begin{tabular}{|c|c|c|}
\hline Kategorija & Kazalnik & Opis \\
\hline \multicolumn{3}{|l|}{ Kompaktnost } \\
\hline $\begin{array}{l}\text { Gost in bližinski } \\
\text { vzorec razvoja }\end{array}$ & $\begin{array}{l}\text { a) rast prebivalstva in urbanega } \\
\text { območja } \\
\text { b) gostota poselitve v urbanem } \\
\text { območju } \\
\text { c) rekonstrukcija obstoječih } \\
\text { stavbnih zemljišč } \\
\text { d) intenzivna uporaba stavb } \\
\text { e) oblika poselitve } \\
\text { f) potovalna razdalja } \\
\text { g) pokritost urbanih zemljišč }\end{array}$ & \begin{tabular}{|l} 
- letna stopnja rasti prebivalstva in urbanega \\
območja znotraj metropolitanske regije \\
- prebivalstvo/velikost urbanega območja znotraj \\
metropolitanske regije \\
- delež urbanega razvoja na obstoječih urbanih \\
zemljiščih v primerjavi z zelenimi površinami \\
- delež praznih stanovanj in poslovnih prostorov \\
- delež večstanovanjskih stavb v številu stavb \\
- povprečna potovalna razdalja na delo/vsa \\
potovanja \\
delež urbanih zemljišč v metropolitanski regiji
\end{tabular} \\
\hline $\begin{array}{l}\text { Urbana območja, } \\
\text { povezana s sistemi } \\
\text { javnega prometa }\end{array}$ & $\begin{array}{l}\text { a) prevozi z javnim prometom } \\
\text { b) bližina javnega prometa }\end{array}$ & 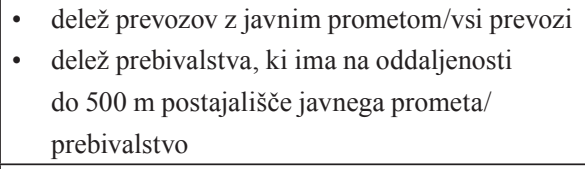 \\
\hline $\begin{array}{l}\text { Dostopnost do } \\
\text { lokalnih storitev } \\
\text { in delovnih mest }\end{array}$ & $\begin{array}{l}\text { a) ujemanje delovnega mesta in } \\
\text { doma } \\
\text { b) ujemanje lokalnih storitev in } \\
\text { domov } \\
\text { c) bližina lokalnih storitev } \\
\text { d) opravljene poti peš ali s } \\
\text { kolesom }\end{array}$ & 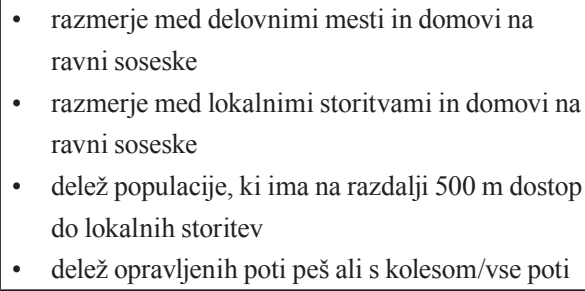 \\
\hline
\end{tabular}




\begin{tabular}{|c|c|c|}
\hline Kategorija & Kazalnik & Opis \\
\hline \multicolumn{3}{|c|}{ Vpliv na urbano trajnost } \\
\hline Okoljski kazalniki & $\begin{array}{l}\text { a) javni prostor in zelena } \\
\text { območja } \\
\text { b) poraba energije za prevoz } \\
\text { c) poraba energije v } \\
\text { stanovanjih }\end{array}$ & 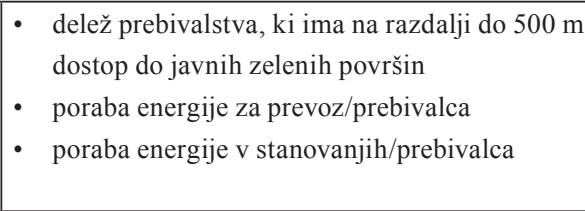 \\
\hline Socialni kazalniki & a) cenovna dostopnost & $\begin{array}{l}\text { - delež izdatkov gospodinjstev za stanovanjske } \\
\text { in prevozne stroške v skupnih izdatkih } \\
\text { gospodinjstev }\end{array}$ \\
\hline $\begin{array}{l}\text { Gospodarski } \\
\text { kazalniki }\end{array}$ & a) javne službe & $\begin{array}{l}\text { - izdatki za vzdrževanje urbane infrastrukture } \\
\text { (ceste, vodni objekti, itd.)/prebivalstvo }\end{array}$ \\
\hline
\end{tabular}

Vir/Source: Compact city ..., 2012

Navedeni kazalniki predstavljajo širok nabor podatkov, ki lahko podajo precej jasno sliko o nekem urbanem območju, vendar pa bi bilo potrebno (predvsem z vidika trajnostnega razvoja) nabor še nekoliko razširiti z določenimi okoljskimi kazalniki, s katerimi bi hitreje ugotovili negativne vplive kompaktnega mesta.

\section{KOMPAKTNO MESTOV SLOVENSKEM PROSTORU}

$\mathrm{Na}$ podlagi značilnosti kompaktnega mesta in kazalnikov za preverjanje kompaktnosti smo želeli preveriti, ali koncept kompaktnega mesta obstaja tudi v slovenskem prostorskem planiranju ter v analizo vključili mesto Ljubljana. Ko govorimo o optimalnem razvoju našega največjega mesta, ne moremo mimo dejstva, da je potrebno tudi pri načrtovanju Ljubljane upoštevati načela trajnosti, če želimo mesto ohraniti za prihodnje rodove, hkrati pa sedanjemu prebivalstvu omogočiti kakovostno življenje v njem. Ker je Ljubljana svoj maksimum v velikosti že dosegla, je potrebno prazne površine iskati znotraj mesta, predvsem na zapuščenih in degradiranih nekdanjih industrijskih in drugih območjih (primer takega območja je na slikah 1, 2 in 3). Pri tem je potrebno poudariti, da mesto na vzhodu in zahodu omejuje Predalpsko hribovje, ki je sicer deloma poseljeno, a je ta poselitev izrazito razpršena. Predvsem je ključnega pomena, da se mesto ne širi več proti severu in jugu, saj bi s tem na severu posegli v pomembna območja podtalnice Ljubljanskega polja, ki so ponekod že poseljena, kar predstavlja izredno nevarnost za kvaliteto pitne vode in bi jo dodatno širjenje mesta še bolj ogrožalo, na južni strani pa je treba ohraniti ekosistemsko pomembno Ljubljansko barje in iz tega vidika nadaljnja širitev ni mogoča. Poleg ekosistemske vloge so za območje Ljubljanskega barja značilne tudi poplave (ob izjemnih poplavah zalije voda velike površine južnih delov Barja, voda pa lahko sega vse do Trnovega) (Gašperič, 2004; Komac, Natek, Zorn, 2008, str. 79-84). Širjenje mesta je tako mogoče le znotraj sedanjih meja, predvsem ob obstoječih krakih pozidave ter koncentrično ob avtocestnem obroču. Čeprav je Ljubljana pomembno zaposlitveno središče za širše območje ter glavni člen v sistemu centralnih krajev Slovenije, 
bi nadaljnja rast Ljubljane negativno vplivala na enakomeren regionalni razvoj države in regije, kar pa je v nasprotju s politiko policentričnega urbanega razvoja Slovenije. Ena od možnih rešitev za nadaljnji razvoj mesta je koncept kompaktnega mesta, ki je kot ena od usmeritev za oblikovanje mesta že vključen v Strateški prostorski načrt MOL (2009).

Sliki 1 in 2: Degradirano industrijsko območje nekdanje Avtomontaže (foto: A. Šulin Košar) Figures 1 and 2: Brownfield site of former Avtomontaža company (photo: A. Šulin Košar)
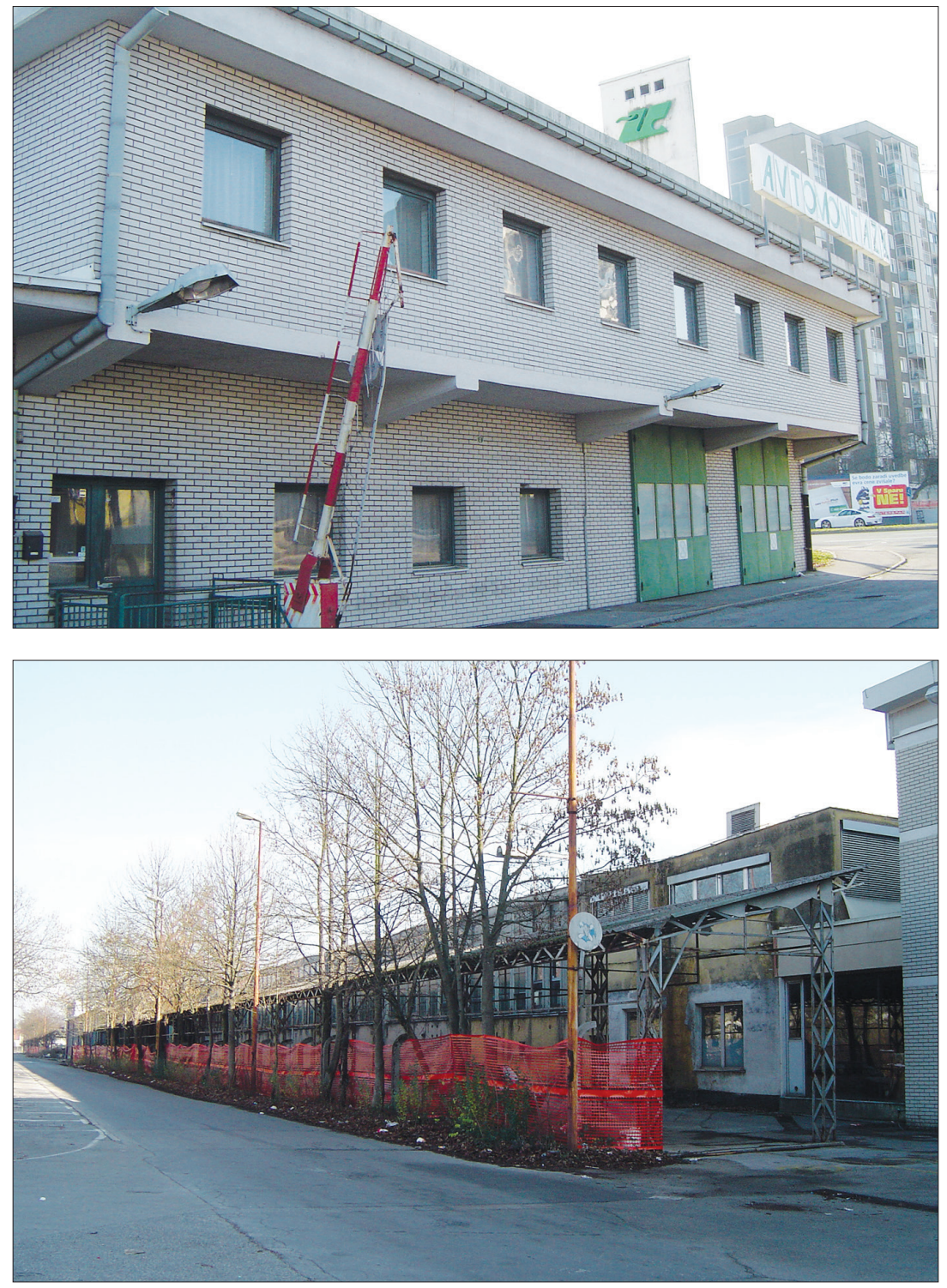
Slika 3: Stanovanjska soseska Celovški dvori na območju nekdanje Avtomontaže (foto: A. Šulin Košar)

Figure 3: Residential neighbourhood of Celovški dvori built in the former area of Avtomontaža company (photo: A. Šulin Košar)

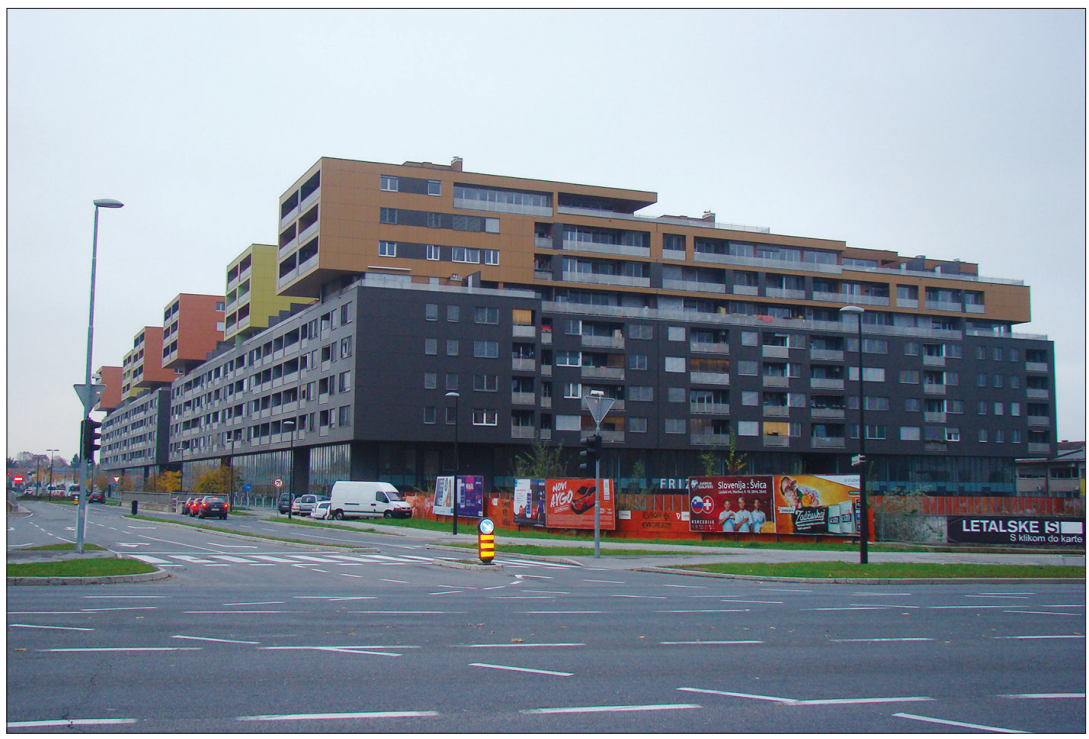

Za uspešen razvoj in delovanje mesta bi se bilo potrebno osredotočiti predvsem na revitalizacijo obstoječih mestnih območij, obnovo degradiranih urbanih območij, enakomerno dostopnost do različnih storitev za vse prebivalstvo, spodbujanje večje raznolikosti in preprečevanje širjenja mestnih območij. A to še ni dovolj, da bi lahko govorili o kompaktnem mestu, saj statistični kazalniki za Ljubljano kažejo, da njen razvoj še ne poteka povsem v skladu s konceptom trajnostnih kompaktnih mest.

V preglednici 3 so prikazani podatki, ki smo jih zbrali za območje mesta Ljubljane oziroma njene urbane regije. Statistični podatki na tako nizkem prostorskem nivoju so sicer precej pomanjkljivi (niso na voljo za vse kazalnike, ki jih je predlagal OECD) in dostopni le za posamezna časovna obdobja (prikazani so najnovejši podatki, vendar iz različnih let), zato ne predstavljajo natančnega stanja, so pa približen pokazatelj trendov. V veliko pomoč je bil evropski projekt Urban Audit (City statistics - Urban Audit, 2014), za katerega Statistični urad RS zbira podatke o mestih Ljubljana, Maribor in Koper. 
Preglednica 3: Kazalniki za analizo politike kompaktnega mesta na primeru Ljubljane Table 3: Compact city policy analysis indicators - Ljubljana case study

\begin{tabular}{|l|l|l|l|}
\hline Kazalnik & & Leto & Vir podatkov \\
\hline Gostota poselitve (preb./km²) & 1018 & 2011 & Statistični letopis Ljubljana 2012 \\
\hline Rast prebivalstva (skupni prirast na 1000 preb.) & 2,0 & 2011 & Statistični letopis Ljubljana 2012 \\
\hline Delež urbanih površin v regiji (\%) & 4,62 & 2006 & OECD \\
\hline Rast urbanih površin v regiji (\%) & 0,11 & 2006 & OECD \\
\hline $\begin{array}{l}\text { Urbane površine, podvržene ukrepom prostorskega } \\
\text { načrtovanja }\left(\mathrm{km}^{2}\right)\end{array}$ & 74,9 & 2003 & Urban Audit \\
\hline Delež prevozov na delo z avtomobilom & 62,9 & 2002 & Urban Audit \\
\hline Delež prevozov na delo z avtobusom & 21,1 & 2002 & Urban Audit \\
\hline Delež prevozov na delo s kolesom & 14,9 & 2002 & Urban Audit \\
\hline Delež poti na delo peš & 0 & 2002 & Urban Audit \\
\hline Povprečen čas poti na delo (minut) & 22 & 2002 & Urban Audit \\
\hline Delež praznih stanovanj/vsa stanovanja (\%) & 17,4 & 2011 & Podatkovni portal SI-STAT, SURS \\
\hline $\begin{array}{l}\text { Število prebivalcev, ki je od javnih zelenih površin } \\
\text { oddaljeno manj kot } 15 \text { minut hoje }\end{array}$ & 270.000 & 2001 & Urban Audit \\
\hline Zelene površine/prebivalca (m²/preb.) & 455 & 2011 & Statistični letopis Ljubljana 2012 \\
\hline Parkovne površine/prebivalca (m²/preb.) & 2,6 & 2011 & Statistični letopis Ljubljana 2012 \\
\hline Poraba električne energije/preb. (kwh) & 6051 & 2011 & Statistični letopis Ljubljana 2012 \\
\hline
\end{tabular}

Kot je razvidno iz podatkov, zbranih v preglednici 3, je za Ljubljano značilna nadpovprečna gostota poselitve (tudi nad slovenskim povprečjem), zato za nadaljnji razvoj ni smiselno še naprej intenzivirati gradnje, oziroma je potrebno za načrtovanje gradnje preveriti gostoto poselitve po soseskah ter iskati že omenjena prazna območja, saj se bo le na ta način ohranila visoka kakovost bivanja v mestu. Iz stopnje rasti prebivalstva je razvidno, da se število prebivalstva $v$ Ljubljani ne povečuje v večji meri, hkrati pa izstopa velik delež praznih stanovanj v mestu. Ta podatek ni povsem realen, saj mnogi lastniki, ki stanovanja oddajajo, ne prijavljajo svoje dejavnosti v uradne evidence. Hkrati je velik delež stanovanj v Ljubljani dotrajan in neprimeren za uporabo, problematična je tudi velikost stanovanj, ki so bila v precejšnji meri zgrajena v prejšnjem stoletju, ko so imela gospodinjstva in družine precej drugačne značilnosti kot danes. Prav te značilnosti obstoječega stanovanjskega fonda nakazujejo, da stanovanj v mestu (kljub stagniranju števila prebivalcev) dejansko ni dovolj in da bi bila potrebna gradnja novih stanovanj. Površine za gradnjo je potrebno iskati na praznih, degradiranih območjih, a je pomembno, da takšna območja opremimo z vsemi potrebnimi dejavnostmi in storitvami (bližina storitev in delovnih mest). S tem bi pripomogli $\mathrm{k}$ bolj mešani rabi takih območij, k čemur teži tudi koncept kompaktnega mesta.

Da bi dobili boljšo sliko o urbaniziranosti preučevanega območja, bi sicer morali pogledati delež urbanih površin, ki pa je na razpolago le za celotno Ljubljansko urbano regijo (v nadaljevanju LUR) in zato ni pravi pokazatelj stanja v mestu. Jasnejšo sliko dobimo pri pregledu kartografskega gradiva iz prostorskih aktov, ki kaže, da je velik delež mesta že pozidan, zato lahko iz tega vidika ugotovimo, da Ljubljana je kompaktno mesto. 
Še največji negativni dejavnik pri načrtovanju kompaktne Ljubljane ostaja promet, saj (daleč) največji delež prevozov opravijo prebivalci in dnevni migranti z avtomobili, zaradi česar so ljubljanske ceste, predvsem vpadnice in obvoznica, med najbolj obremenjenimi cestami v državi. Da bi zadostili tudi pogojem trajnostnega razvoja in ne samo konceptu kompaktnega mesta, bi bilo nujno potrebno v mestu vzpostaviti učinkovit sistem javnega potniškega prometa, ne samo znotraj mesta, temveč tudi znotraj LUR, predvsem $\mathrm{z}$ vidika pokritosti območja s progami, rednimi linijami, večjo frekvenco povezav in tako ugodnimi cenami prevoza, da bi se prebivalci raje odločali za javni promet.

Potrebno bi bilo spodbujati tudi okolju prijazno kolesarjenje (ki se v določeni meri že spodbuja s projektom BicikeLj) in hojo. Z mrežo javnega potniškega prometa bi se hkrati zmanjšale emisije iz prometa. Sedanji trendi kažejo, da se število prepeljanih potnikov v javnem prometu manjša, medtem ko število avtomobilov narašča, $s$ tem pa se povečujejo onesnaženost zraka in tal, hrup ter negativni vplivi prometnih nesreč. Povečana uporaba osebnih avtomobilov vodi tudi do zastojev, zasičenosti v prometu in povečanja vlaganj v cestno infrastrukturo. S povečanjem osebne mobilnosti se po mnenju Šašek Divjakove (2002) povečuje razpršenost poselitve, kar je v nasprotju s konceptom kompaktnega mesta, hkrati pa se povečujejo tudi skupni visoki stroški lokalne skupnosti.

Vse te negativne trende je potrebno $v$ mestu preprečiti v najkrajšem možnem času. Ob tem je potrebno težiti tudi k zmanjšanju drugih emisij ter predvsem $\mathrm{k}$ porabi naravnih virov in energije, saj ima Ljubljana visok delež v porabi energije in ustvarjanju emisij v Sloveniji. Energetska bilanca mest je namreč pomemben posredni kazalec pokrajinske degradacije mestnih območij (Plut, 2006).

Slika 4: Postajališče Kino Šiška, del sistema BicikeLj (foto: A. Šulin Košar) Figure 4: City bike station Kino Šiška, one of the stations of the system BicikeLj (photo: A. Šulin Košar)

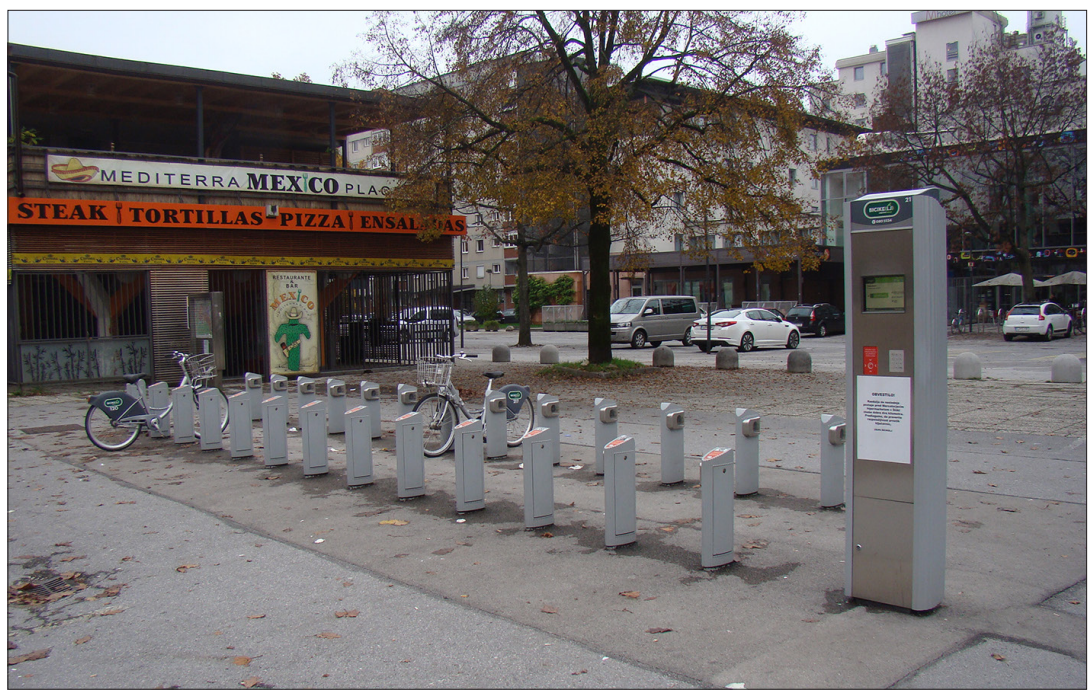


Pri razvoju mesta je sicer potrebno upoštevati tudi druge dejavnike, predvsem dostopnost prebivalstva do javnih služb in storitev ter zelo pomembnih rekreacijskih in zelenih površin, ki jih je v mestu potrebno še naprej ohranjati, zato gradnja na teh območjih ni dopustna. Z vidika varovanja okolja je potrebno ohraniti predvsem zelene kline med pozidanimi kraki mesta, ki potekajo od širšega odprtega prostora do mestnega središča, saj omogočajo tudi boljšo prevetrenost mesta, obenem pa se z dostopnostjo zelenih površin za vse prebivalstvo veča kvaliteta življenja v mestu.

S stalno kontrolo razvoja mesta in ukrepov, ki bi negativne posledice pravočasno preprečili, a hkrati tudi razvojnimi projekti, kot je sistem učinkovitega javnega prometa, bi Ljubljana lahko postala trajnostno kompaktno mesto, ki bi omogočilo kvalitetno življenje vseh njenih sedanjih in prihodnjih prebivalcev.

\section{SKLEP}

Kljub številnim avtorjem, ki so se v urbanistični literaturi ukvarjali s teorijo kompaktnih mest, je jasno, da tudi oni niso enotni glede definicije kompaktnega mesta, kakšne so njegove oblike in katere so prednosti ter slabosti take ureditve. Kljub temu so si enotni, da se kompaktno mesto naj ne bi širilo izven obstoječih meja mesta, temveč naj bi pri razvoju izkoristili obstoječo velikost mesta in zemljišča. Iz tega lahko izhajamo, da enotnega modela za vsa mesta ni, saj imajo ta različno preteklost in razloge za specifičen urbanistični razvoj, kar pomeni, da so kompaktna mesta lahko različnih velikosti in oblik. Glavni poudarek v kompaktnem mestu je pri vseh avtorjih učinkovit sistem javnega potniškega prometa, skrajšanje razdalj in časa potovanj, prenova in ponovna uporaba že obstoječih, a zapuščenih (degradiranih) zemljišč, ter ne nazadnje kakovost življenja v mestu. Ravno ta dejavnik je najbolj problematičen, saj nihče ne zna natančno opredeliti, kdaj bo mesto še privlačno za njegove prebivalce in kdaj bo življenje v mestu prinašalo več slabosti kot prednosti v primerjavi z življenjem v suburbanih in ruralnih območjih izven mesta.

Poleg ohranjanja kakovosti življenja v mestu je glavni problem kompaktnega mesta ohranjanje zelenih površin, oziroma gradnja, ki ne posega v mestne zelene otoke. Kljub nekaterim pomislekom, ki jih koncept prinaša, najdemo predvsem v Zahodni in Severni Evropi mesta, ki uspešno izvajajo politiko kompaktnega mesta. To so npr. London, Stockholm, København in Hamburg, katerih prakse jasno kažejo, da so vsa ta mesta z uvedbo koncepta kompaktnih mest $\mathrm{v}$ načrtovanje mesta in prostorske plane dosegla ustavitev nenadzorovanega širjenja na obrobje, a ne na račun zelenih površin v mestu, temveč s prenovo degradiranih urbanih območij, v večini primerov zapuščenih industrijskih ali pristaniških območij. S tem so pridobili nove stanovanjske površine, ki so bile na podlagi projekcij prebivalstva, predvsem pa potrebah po stanovanjih, nujno potrebna. Hkrati je vsem tem mestom skupno, da spodbujajo trajnostni razvoj, torej razvoj, ki naj bi današnje mesto ohranil tudi za bodoče generacije. Ob tem težijo k čim večji uporabi javnega prometa, hoje ter vožnje s kolesom, zmanjšanju uporabe osebnih vozil ter zmanjšanju emisij, gradijo pa tudi sisteme za ločevanje odpadkov in čiščenje odpadnih vod. 
Koncept kompaktnih mest je v svojem bistvu lahko precej uspešen način urejanja sodobnih mest, vendar mora upoštevati tudi trajnostni razvoj, h kateremu težijo tako slovenski državni prostorski dokumenti kot tudi vsi evropski dokumenti s področja prostorskega in urbanističnega planiranja. Da je temu res tako, priča tudi obstoječi prostorski plan mesta Ljubljane, ki kaže, da se koncept kompaktnega mesta uvaja tudi v slovenski prostor. Pri tem je pomembno, da načrtovalci skrbno spremljajo razvoj v mestu in pravočasno preprečijo morebitne negativne posledice, ki lahko nastanejo ob intenzifikaciji rabe mestnega prostora.

\section{Viri in literatura}

Arbury, J., 2005. From urban sprawl to compact city - an analysis of urban growth management in Auckland. Master thesis. Auckland, University of Auckland, 175 str. URL: http://transportblog.co.nz/wp-content/uploads/2009/06/thesis.pdf (Citirano 10. 4. 2010).

Breheny, M., 1998. Centrists, decentrists and compromisers: views on the future of urban form. V: Jenks, M., Burton, E., Williams, K. (ur.). The compact city: a sustainable urban form? London, New York, E \& FN Spon, str. 13-35.

Cities data book. Urban indicators for managing cities. 2001. Manila, Asian Development Bank, 460 str. URL: http://www.adb.org/publications/urban-indicators-managing-cities (Citirano 20. 4. 2014).

City statistics - Urban Audit. 2014. Eurostat. URL: http://epp.eurostat.ec.europa.eu/portal/page/portal/region_cities/city_urban (Citirano 15.4. 2014).

Compact city policies: a comparative assessment. 2012. Pariz, OECD Publishing, 284 str. DOI: $10.1787 / 9789264167865$-en

Dantzig, G. B., Saaty, T. L., 1973. Compact city: plan for a livable urban environment. San Francisco, W. H. Freeman \& Co, 255 str.

Dimitrovska Andrews, K., Mihelič, B., Stanič, I., 2001. Razpoznavna struktura mesta: primer Ljubljane. Urbani izziv, 12, 1, str. 5-16. URL: http://urbani-izziv.uirs.si/Portals/uizziv/papers/urbani-izziv-2001-12-02-001.pdf (Citirano 20. 4. 2014).

Elkin, T., McLaren, D., Hillman, M., 1991. Reviving the city: towards sustainable urban development. London, Friends of the Earth Trust, 278 str.

Frey, H., 1999. Designing the city: towards a more sustainable urban form. London, E \& FN Spon, 148 str.

Gašperič, P., 2004. Širitev Ljubljane na Ljubljansko barje. Acta geographica Slovenica, 44, 2, str. 7-33. DOI: 10.3986/AGS44201

Global city indicators facility. 2014. Toronto, Global Cities Institute. URL: http:/www. cityindicators.org (Citirano 20. 4. 2014).

Gossop, C., 2008. Towards a more compact city - the plan for London. URL: http://www. isocarp.net/Data/case_studies/442.pdf (Citirano 15. 4. 2014).

Green paper on the urban environment. 1990. Commission of the European Communities. URL: http://ec.europa.eu/green-papers/pdf/urban_environment_green_paper_ com_90_218final_en.pdf(Citirano 20.11.2011). 
Hammer, S., Kamal-Chaoui, L., Robert, A., Plouin, M., 2011. Cities and green growth: a conceptual framework. OECD regional development working papers, 2011, 8, 141 str. URL: http://www.oecd-ilibrary.org/governance/cities-and-green-growth_5kg0tflmzx34-en (Citirano 20. 11. 2014).

Haughton, G., 1994. Sustainable cities. London, Jessica Kingsley Publishers, 368 str.

Jenks, M., Burton, E., Williams, K., 1998. The compact city: a sustainable urban form? London, New York, E \& FN Spon, 350 str.

Komac, B., Natek, K., Zorn, M., 2008. Geografski vidiki poplav v Sloveniji. Ljubljana, Založba ZRC, 180 str.

Koželj, J., 2007. Opredelitev sodobnega mesta. V: Čerpes, I., Dešman, M. (ur.). O urbanizmu. Kaj se dogaja s sodobnim mestom? Ljubljana, Krtina, str. 195-208.

Neuman, M., 2005. The compact city fallacy. Journal of planning education and research, 25, 1, str. 11-26. DOI: 10.1177/0739456X04270466

OECD Metropolitan eXplorer. OECD. URL: http://measuringurban.oecd.org/\# (Citirano 15. 4. 2014).

Pemer, M., 2001. Developing a sustainable compact city in Stockholm, Sweden. Thematic Committee 6-8 June 2001, Istanbul, 7 str. URL: http://www.un.org/ga/Istanbul+5/ 7-Sweden.doc (Citirano 20. 11. 2011).

Plut, D., 2006. Mesta in sonaravni razvoj. Ljubljana, Znanstvenoraziskovalni inštitut Filozofske fakultete, $226 \mathrm{str}$.

Plut, D., 2007. Ljubljana in izzivi sonaravnega razvoja. Ljubljana, Oddelek za geografijo Filozofske fakultete, 183 str.

Podatkovni portal SI-STAT: Splošno: Medpodročni kazalniki: Projekt Urban Audit podatki o mestih Ljubljana in Maribor. Statistični urad RS. URL : http://pxweb.stat. si/pxweb/Database/Splosno/26_kazalniki/30_26549_UrbAudit/30_26549_UrbAudit. asp (Citirano 24. 4. 2014).

Podatkovni portal SI-STAT: Demografsko in socialno področje: Življenjska raven: Naseljena in nenaseljena stanovanja, občine. Statistični urad RS (Registrski popis 2011). URL: http://pxweb.stat.si/pxweb/Database/Dem_soc/08_zivljenjska_raven/25_STANOVANJA/02_08611-stanovanja_OBC/02_08611-stanovanja_OBC.asp (Citirano 15. 4. 2014).

Statistični letopis Ljubljana 2012. 2013. Ljubljana, Mestna občina Ljubljana, Mestna uprava, Služba za razvojne projekte in investicije, Odsek za razvojne projekte, Referat za statistiko in analize, 114 str. URL: http://www.ljubljana.si/file/1405735/mol_letopis_slo_2012-.pdf (Citirano 10. 4. 2014).

Strateški prostorski načrt MOL. Dopolnjeni osnutek. 2009. Ljubljana, Mestna občina Ljubljana, Mestna uprava, Oddelek za urejanje prostora, 95 str. URL: https://urbanizem.ljubljana.si/index2/files/SPN_MOL_Odlok.pdf (Citirano 10. 4. 2014).

Šašek Divjak, M., 2002. Širjenje mesta s poudarkom na urbani mobilnosti - primeri iz ZDA. Urbani izziv, 13, 2, str. 34-44. DOI: 10.5379/urbani-izziv-2002-13-02-005

Šulin, A., 2007. Preobrazba industrijskih območij v Mestni občini Ljubljana. Diplomsko delo. Ljubljana, Filozofska fakulteta, Oddelek za geografijo, 109 str. 
Thomas, L., Cousins, W., 1998. The compact city: a successful, desirable and achievable urban form? V: Jenks, M., Burton, E., Williams, K. (ur.). The compact city: a sustainable urban form? London, New York, E \& FN Spon, str. 53-65.

Urban indicators. 2014. UN-Habitat. United Nations Human Settlements Programme. URL: http://ww2.unhabitat.org/programmes/guo/urban_indicators.asp (Citirano 20. 4. 2014).

Williams, K., Burton, E., Jenks, M., 1998. Achieving the compact city through intensification: an acceptable option? V: Jenks, M., Burton, E., Williams, K. (ur.). The compact city: a sustainable urban form? London, New York, E \& FN Spon, str. 83-96.

\section{SUSTAINABLE COMPACT CITY}

\section{Summary}

In 1987, the Brundtland Commission introduced the concept of sustainable development, which became an important factor at all levels of spatial development. One of the solutions for sustainable urban development is the concept of the compact city, which has been established in many European countries. The concept is very different from usual urban development, as it emphasizes urban intensification, creates limitations for urban growth, promotes multi-purpose development and places greater emphasis on the role of public transport and high-quality urban planning.

A sustainable city promotes mixed use of urban land, environmentally friendly transportation system, protection of natural and cultural heritage, improvement of quality of living and sustainable use of natural resources. Mixed use reduces the number and distance of daily journeys, while preservation of green areas in the city centre allows for the connection with transitional green regional system and the equalization of living conditions in urban and rural areas. The sustainable ideal of the 21 st century is not multimillion cities. Nowadays, an ideal city is a dense, compact, manageable city that saves space and solves communication traffic problems.

Defining a compact city is a difficult task, since there does not exist a single model of the compact city. However, three main characteristics can be highlighted:

- a model of development that emphasizes density and proximity;

- urban areas linked to the public transport system;

- accessibility to local services and jobs.

Dantzig and Saaty (1973) are considered to have first made use of the term compact city. In their opinion the main characteristics of such city are:

- urban form: high, dense settlements, less dependence on automobiles, clear boundary with surrounding areas;

- spatial characteristics: mixed land use, diversity, clear identity;

- social characteristics: social fairness, self-sufficiency of daily life, independent government. 
Other authors wrote about the compact city as well. Among some of the authors it is widely believed that a compact city should look like a medieval town with concentration of activities in a very dense city centre with a clear line between the city and countryside. Haughton (1994), on the other hand, concluded that there could exist different forms of a compact city:

- large concentrated centres;

- decentralized, but concentrated and compact settlements, connected by public transport;

- $\quad$ scattered self-sufficient communities.

In exploring the concept of a compact city, several authors have exposed both the strengths and weaknesses of this concept. Frey (1999), for example, highlighted the following benefits:

- a high degree of containment of urban development (re-use and rejuvenation of existing urban areas);

- affordable public transport (increase of accessibility and mobility);

- reduced negative impacts of transport;

- $\quad$ survival of mixed use of urban land and reduced travel distances, cycling and walking as the most energy-efficient way to access local facilities;

- better environment and health (lower emissions);

- lower heating costs as a result of dense urban structures with lower energy consumption and less pollution;

- the potential mixing of different social groups as a result of high population density;

- the concentration of activities in local communities and neighbourhoods - the result is a high quality of life, greater security and a more vibrant environment as well as support for business and services.

Frey (1999) also identified several weaknesses:

- the concept of the compact city is at odds with the growing popularity of suburban and semirural areas; especially at high densities the benefits may turn into weaknesses through the congestion that would outweigh the benefits of energy consumption in a compact city;

- the concept of a green city (which is also promoted by the European Commission) is in contradiction with the concept of the compact city;

- compact city policy would lead to the neglect of rural communities and previously generated growth centres that occurred during the policy of diversification;

- a compact city would cause congestion with increased pollution, loss of amenity space and would reduce privacy;

- in a compact city, an increased racial segregation because of the high cost of housing in the city centre and in the outer more privileged suburbs could be a problem.

Unlike Frey, the OECD concept of the compact city (Compact city ..., 2012) sees mainly the benefits of such a policy. In their opinion, the negative consequences can be avoided before realization. The OECD recognizes six characteristics of the compact city which contribute to achieving urban sustainability: 
- shorter intra-urban travel distances;

- less automobile dependency;

- more district-wide energy utilisation and local energy generation;

- optimal use of land resources and more opportunity for urban-rural linkage;

- more efficient public service delivery;

- better access to a diversity of local services and jobs.

Due to concerns raised in the previous paragraphs, it is necessary to include comparable indicators to monitor the effectiveness of compact city policies. The OECD (Compact city ..., 2012) proposed $18 \mathrm{key}$ indicators for analysing compactness and the impact of the compact city on urban sustainability:

- population and urban land growth;

- population density on urban land;

- retrofitting of existing urban land;

- intensive use of buildings;

- housing form;

- trip distance;

- urban land cover;

- trips using public transport;

- proximity to public transport;

- matching jobs and homes;

- matching local services and homes;

- proximity to local services;

- trips on foot and by bicycle;

- public space and green areas;

- transport energy use;

- residential energy use;

- affordability;

- public service.

The European Union, OECD, and several countries emphasize the importance of the compact city in their development documents, as they see in the concept one of the solutions for urban spatial development. Despite some reservations that the concept brings, we can find several cities in Western Europe that have successfully implemented the policy of the compact city, among them London, Stockholm, Copenhagen and Hamburg. Their experiences clearly show that with the introduction of the compact city concept in city planning, such cities stopped their uncontrolled expansion to the periphery, not at the expense of green areas in the city, but rather with the redevelopment of brownfield areas that are in most cases abandoned industrial or port areas.

The concept of compact city can in its essence be a quite successful way of regulating modern cities, but must also take into account sustainable development. This duality is represented in Slovenian national spatial documents, as well as in all European spatial and urban planning documents. A good example is the current spatial plan of the city of 
Ljubljana that provides the compact city concept as one of the important guidelines for designing the city. It is important that planners monitor the city development and avoid any negative consequences that may arise from the intensification of urban space.

(Translated by the author) 